\title{
Brachial Plexopathy as Early Manifestation of Hereditary Neuropathy with Liability to Pressure Palsy (Hnpp) in Infancy
}

Teodoro Dura-Trave ${ }^{1 *}$ Fidel Gallinas Victoriano $^{1}$, María Asunción Ibiricu-Yanguas ${ }^{2}$ and María Antonia Ramos Arroyo ${ }^{3}$

${ }^{1}$ Department of Pediatrics, Navarra Hospital Complex, Pamplona, Spain

${ }^{2}$ Neurophysiology Unit, Navarra Hospital Complex, Pamplona, Spain

${ }^{3}$ Department of Genetic, Navarra Hospital Complex, Pamplona, Spain

\begin{abstract}
Hereditary neuropathy with liability to pressure palsy (HNPP) is an autosomal dominant disorder characterized by recurrent mono-neuropathies related to minimal trauma o compression. HNPP usually manifests in adolescence or adulthood, being relatively exceptional at an earlier age. A 4-month-old boy with brachial plexopathy as early manifestation of HNPP is presented. Familiar anamnesis, as well as neurophysiological and molecular studies, stands out in early diagnostic suspicion. In this case, the early manifestation and its semiological characteristics accentuate its peculiarity.
\end{abstract}

Keywords: Brachial plexopathy; Infancy; Hereditary neuropathy with liability to pressure palsy

\section{Introduction}

Hereditary neuropathy with liability to pressure palsy (HNPP) is a sensitive motor neuropathy inherited in an autosomal dominant pattern whose anomaly consists of a deletion of the peripheral myelin protein 22 (PMP22) gene, located in the 17p11.2 chromosome region. Its clinical characterization reveals recurrent episodes related to minimal trauma, such as traction and/or external pressure. This diagnosis is rare in the paediatric age [1-4]. We present a case of HNPP with clinical manifestations at an early age (4 months). Familiar anamnesis, as well as neurophysiological and molecular studies, stand out in early diagnostic suspicion.

\section{Case Report}

We present a case of a four month infant attending a well-child examination, showing less mobility in left upper limb (the left arm standing in approximation and internal rotation). There were no previous traumatisms of evident traction. Massages and passive exercises of the articulations of the upper limb were recommended showing a progressive improvement with complete recovery after fivesix weeks. Neurological examination was normal at six months of age. His father, aged 40 , pointed out that he presented weakness in upper right limb, associated to sensitive disorder (numbness) during several weeks when carrying relatively heavy objects (such as the shopping bag). In addition, his sister and her daughter (aged 50 and 28, respectively), as well as his brother (aged 43) referred similar symptoms (his brother worked as a waiter and had to quit his job because of recurrent episodes of weakness and loss of manual skill). His paternal grandfather, who is now dead, seemed to have suffered the same symptoms. Our patient has a six year old sister who refers weakness and recurrent limb paresthesia (her parents did not will to achieve molecular and neurophysiological studies). Pregnancy was normal and showed low fetal movement (an amniocentesis was required because of age over 35: normal karyotype 46, XY). A forceps delivery was required. Birth weight was $3400 \mathrm{~g}$ and reanimation was not necessary (Apgar score: 9/10).

A psychomotor retardation and/or motor impairment was gradually appreciated (rolling from back to side at age 11 months, unsupported sitting at 14 months, able to walk unassisted at 20 months of age). Blood analysis (hemogram, calcium and phosphate, ferritin, creatine phosphokinase, liver and renal function tests, thyroid hormones, pyruvate, ammonia and amino acids) and urine analysis (organic acids and amino acids) as well as cranial MRI were normal $\mathrm{He}$ is four years old at present, shows relatively steady unsupported walking, but has difficulties to jump in place with both feet together and stand on one foot. He did not present any additional neuropathic episode.

At age 10 months, electromyography and peripheral nerve conduction studies were normal. At age 15 months, peripheral nerve conduction was normal, except for a slight alteration of median nerve at wrist. At age three years, studies showed a moderate decrease in peripheral motor and sensory nerve conduction velocities with lower limbs predominance, as well as alteration in right median nerve at wrist (distal latency: $5.7 \mathrm{~ms}$ ) and, to a lesser extent, in right popliteal sciatic nerve at the fibular head (distal latency: $10.7 \mathrm{~ms}$ ) (Table 1). The neurophysiological studies performed in his father and affected uncles showed generalized slowing of motor and sensory conduction with a higher expressivity in usual focal compression places (ulnar neuropathy at the elbow in all three, and important conduction alteration of the right median and left popliteal sciatic nerves, at carpal tunnel and fibular head, respectively, in his father). A molecular genetic study (Figure 1) was performed in affected relatives by gene amplification using the SALSA P033B kit containing 37 probes, 16 of which are specific for the PMP22 (17p11.2) gene region. The amplified fragments were analyzed with automated DNA sequencing by capillary electrophoresis and showed a hybridization pattern compatible with the presence of reduced PMP22 gene dosage (deletion).

\section{Discussion}

The HNPP usually manifests during adolescence and/or adulthood, being relatively exceptional at an earlier age [5-10]. Its clinical manifestations usually correspond to anatomical locations

*Corresponding authors: Dura Trave T, Department of Pediatrics, Navarra Hospital Complex, Pamplona, Avenue Irunlarrea 4, 31008 Pamplona, Spain, Tel: +34 8484221 00; Fax: 8484299 24; E-mail: tduratra@cfnavarra.es

Received October 16, 2014; Accepted November 16, 2014; Published November 18, 2014

Citation: Dura-Trave T, Victoriano FG, Ibiricu-Yanguas MA, Arroyo MAR (2014) Brachial Plexopathy as Early Manifestation of Hereditary Neuropathy with Liability to Pressure Palsy (Hnpp) in Infancy. J Clin Case Rep 4: 450. doi:10.4172/2165 7920.1000450

Copyright: (c) 2014 Dura-Trave T, et al. This is an open-access article distributed under the terms of the Creative Commons Attribution License, which permits unrestricted use, distribution, and reproduction in any medium, provided the original author and source are credited. 


\begin{tabular}{|c|c|c|c|c|c|c|c|}
\hline \multirow[b]{2}{*}{ Nerve } & \multirow[b]{2}{*}{ Stimulation-record sites } & \multicolumn{2}{|c|}{$\begin{array}{c}\text { Amplitude } \\
(\mathrm{M}=\mathrm{mV} ; \mathrm{S}=\mu \mathrm{V})\end{array}$} & \multicolumn{2}{|c|}{$\begin{array}{l}\text { Distal latency } \\
\quad(\mathrm{ms})\end{array}$} & \multicolumn{2}{|c|}{ Conduction velocity $(\mathrm{m} / \mathrm{s}$} \\
\hline & & $\mathrm{R}$ & $\mathrm{N}$ & $\mathrm{R}$ & $N$ & $\mathrm{R}$ & $\mathrm{N}$ \\
\hline Sural & Calf-Ankle & 4 & $>5$ & 2.1 & $<3.5$ & 20 & $>45$ \\
\hline Median sensory & Wrist-Digit 2 & 4 & $>8$ & 4 & $<3.4$ & 20 & $>50$ \\
\hline Ulnar sensory & Wrist-Digit 5 & 5 & $>5$ & 1.8 & $<3.1$ & 40 & $>50$ \\
\hline \multirow[t]{2}{*}{ Median motor } & Wrist-APB & 5 & $>5$ & 5.7 & $<4$ & & \\
\hline & Elbow & 4 & & 8.2 & & 56 & $>50$ \\
\hline \multirow[t]{2}{*}{ Ulnar motor } & Wrist-ADM & 7 & $>6$ & 2.8 & $<3.3$ & & \\
\hline & Elbow & 6 & & 6.1 & & 51 & $>50$ \\
\hline \multirow[t]{2}{*}{ Peroneal motor } & Ankle-EDB & 0.7 & $>2.5$ & 5.1 & $<5$ & & \\
\hline & Fibular head & 0.7 & & 10.7 & $<9.3$ & 37 & $>45$ \\
\hline \multirow[t]{2}{*}{ Tibial motor } & Ankle-AH & 4 & $>3$ & 3.3 & $<5.5$ & & \\
\hline & Poplitea & 4 & & 8.3 & & 38 & $>45$ \\
\hline
\end{tabular}

Table 1: Nerve conduction study results of the patient.

P033 08/0942

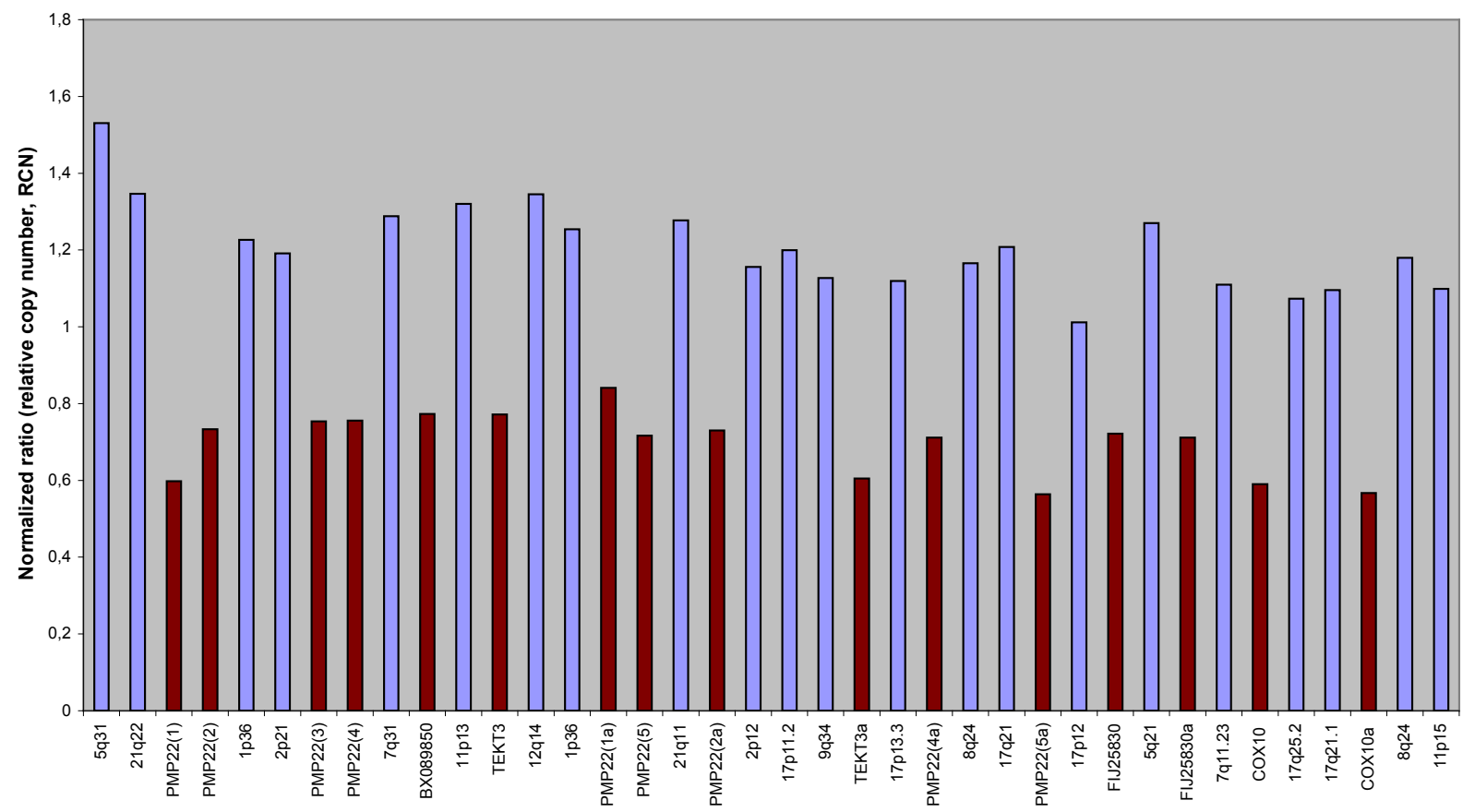

Figure 1: MLPA P033-B graph of the PMP22 deletion. Brown bars show deleted specific probes in 17p11.2 region (normalized ratio decreased in 35$50 \%$ ) with respect to the blue bars which represent the balanced control probes.

subject to compression or entrapment, such as the external popliteal sciatic nerve at fibular head, ulnar nerve at the elbow, radial nerve at the humerus and/or the armpit or median nerve in the carpal tunnel $[7,9,10]$. However, any peripheral or even cranial nerve could be affected. It is characterized by painless motor weakness, which tends to complete recovery in a short period of time, although a certain neurological deficit might persist in adult life. A favourable prognosis is expected and, in many cases, symptoms are barely perceptible, which justifies the neurophysiological and/or genetic studies in the relatives of a previously diagnosed patient. In this case, the father of the patient, as well as the affected relatives, had an officially recognized degree of disability, and the work duties were conditioned by the symptoms. In this case, the early manifestation (four months of age), and its semiological characteristics accentuate its peculiarity. Symptoms reflect a brachial plexopathy whose lesion apparently settled on the Erb point, where C5 and C6 roots merge to form the upper trunk of the brachial plexus and therefore affecting the innervation of the deltoid and arm muscles without involving the muscles of hand and forearm. The developmental delay and/or clumsiness in motor skills, as were stated in this patient, are associated manifestations which have been described in the few patients diagnosed in early age [5,6]. They were obviously included in early stimulation programs.

The peculiarities of this case (transient brachial plexopathy without evident etiological factor in an infant) could have caused a delay in diagnostic suspicion. The presence of familiar history facilitated an early diagnosis. The anamnesis data -even without a previous familiar diagnosis- guided to the possibility of a hereditary polyneuropathy. For this reason, molecular and neurophysiological study was mandatory [7]. The neurophysiological studies showed a characteristic 
Citation: Dura-Trave T, Victoriano FG, Ibiricu-Yanguas MA, Arroyo MAR (2014) Brachial Plexopathy as Early Manifestation of Hereditary Neuropathy with Liability to Pressure Palsy (Hnpp) in Infancy. J Clin Case Rep 4: 450. doi:10.4172/2165-7920.1000450

electroneurogram in the patient as well as in the affected relatives: signs of generalized sensitive and motor polyneuropathy showing higher expressivity in usual focal compression places whose specificity allows differential diagnosis with other polyneuropathies [11]. However, we remark the possible need to accomplish evolutionary controls in those cases with early symptoms, since the specific electroneurographic pattern might appear at later stages of the disease, as it occurred in this patient. On the other hand, molecular analysis of the patient and his relatives confirmed the PMP22 gene deletion usually associated to HNPP although there are some cases with point mutation on the same gene $[2-4,12]$. When neurophysiological and, specially, molecular studies are decisive, as in this case, the sural nerve biopsy (which helps detect focal myelin thickening or tomaculas, characteristic of this pathology) can be avoided [10,13]

\section{References}

1. Verhagen WI, Gabreëls-Festen AA, van Wensen PJ, Joosten EM, Vingerhoets HM, et al. (1993) Hereditary neuropathy with liability to pressure palsies: a clinical, electroneurophysiological and morphological study. J Neurol Sci 116: 176-184.

2. Gouider R, LeGuern E, Gugenheim M, Tardieu S, Maisonobe T, et al. (1995) Clinical, electrophysiologic, and molecular correlations in 13 families with hereditary neuropathy with liability to pressure palsies and a chromosome 17p11.2 deletion. Neurology 45: 2018-2023.

3. Mouton P, Tardieu S, Gouider R, Birouk N, Maisonobe T, et al. (1999) Spectrum of clinical and electrophysiologic features in HNPP patients with the 17p11.2 deletion. Neurology 52: 1440-1446.

4. Hong YH, Kim M, Kim HJ, Sung JJ, Kim SH, et al. (2003) Clinical and electrophysiologic features of HNPP patients with 17p11.2 deletion. Acta Neurol Scand 108: 352-358.

5. de las Cuevas I, Arteaga R, García A, Herranz JL (2000) Hereditary neuropathy with liability to pressure palsies in childhood. Rev Neurol 31: 38-41.

6. Goikhman I, Meer J, Zelnik N (2003) Hereditary neuropathy with liability to pressure palsies in infancy. Pediatr Neurol 28: 307-309.

7. Bayrak AO, Battaloglu E, Turker H, Baris I, Oztas G (2009) Hereditary neuropathy with liability to pressure palsy (HNPP) in childhood: A case study emphasizing the relevance of detailed electrophysiological examination for suspected HNPP in the first decade. Brain Dev 31: 445-448.

8. Ichikawa K, Nezu A (2005) Hereditary neuropathy with liability to pressure palsies in childhood: report of a case and a brief review. Brain Dev 27: 152-154.

9. Cruz-Martinez A, Arpa J (1998) Pediatric bilateral carpal tunnel syndrome as first manifestation of hereditary neuropathy with liability to pressure palsies (HNPP). Eur J Neurol 5: 316-317.

10. Eirís-Punal J, Vidal-Lijo M, Barros Angueira F, Lopez-Fernández MJ, Pintos Martínez E, et al. (2000) Hereditary neuropathy with liability to pressure palsies (tomaculous neuropathy). Clinical, electrophysical and molecular study of two affected families. Rev Neurol 31: 506-510.

11. Chance PF (2006) Inherited focal, episodic neuropathies: hereditary neuropathy with liability to pressure palsies and hereditary neuralgic amyotrophy. Neuromolecular Med 8:159-1574.

12. Lenssen PP, Gabreëls-Festen AA, Valentijn LJ, Jongen PJ, van Beersum SE, et al. (1998) Hereditary neuropathy with liability to pressure palsies. Phenotypic differences between patients with the common deletion and a PMP22 frame shift mutation. Brain 121 : 1451-1458.

13. Vital A, Vital C, Latour P, Ferrer X, Rouanet-Larivière M, et al. (2004) Periphera nerve biopsy study in 19 cases with $17 \mathrm{p} 11.2$ deletion. J Neuropathol Exp Neurol 63: 1167-1172. 